\title{
AZ IDŐSKORI ÉLELMISZERFOGYASZTÁS MAGYARORSZÁGI VONATKOZÁSAI ÉS IDỎBELI ASPEKTUSAI
}

\author{
Dr. PhD Véghová Katarína \\ egyetemi adjunktus, J. Selye University in Komárno, Faculty of Economics
}

\section{SUMMARY}

Aging is not only a challenge for food producers, but also provides a treasure trove of new opportunities for product development and innovations. We have designed a prototype model of food consumption of the elderly with the goal of calling the attention of producers and growers to the specific needs of this growing market segment. However, the food consumption habits of the elderly cannot be compacted into a single model, since this specific age group is not homogenous. By designing hypothetical models we are hoping to facilitate the further research of the issue. In the near future we want to test and try our general models in practice, involving the producers as well as the consumers. The models point at the specific needs of aging populations and their choice of food products based upon reasonable decisions and focusing on the future. Considerations of the future perspective are an important feature of this behavior, since it might significantly improve the quality of life and health awareness of the elderly, their decisions in the field of consumption, and ultimately their general health and welfare conditions.

Keywords: aging population, food consumption behavior model, longevity

\section{BEVEZETÉS}

A fogyasztói magatartáson belül az élelmiszerfogyasztói magatartás több szempontból is speciális helyet jelent. Egyrészt az ember létfenntartásához kapcsolódik közvetlenül vagy közvetve, másrészt hosszú biológiai, társadalmi, kulturális folyamatok eredménye, harmadrészt a legkomplexebb emberi magatartásformák egyike. Az élelmiszerfogyasztói magatartás korlátozottan racionális, mivel az információellátottság tökéletlen a kevés vagy a túl sok információ következtében. Az egyén korlátozott információ feldolgozó és értékelö képessége, a jövőre vonatkozó információk valószínüsége, valamint a piaci szereplök közti aszimmetrikus információ is ez irányban hatnak. A korlátozott információ (fogyasztás elött, alatt és után) és arra épülő érzékelés és észlelés (tapasztalat, tudás, emlékezés, stb.) a kristálytiszta racionalitáshoz képest torzított eredményre vezet. A torzítás nem tudatos, hanem tudat alatti tényezỏkön alapul.

A fiatal, a középkorú és az idős generáció közötti fogyasztásbeli különbség nem vitatott (CSERES-GERGELY-MOLNÁR, 2008). Kijelenthetỏ, hogy a korosodás folyamatának fentebb bemutatott univerzalitása újabb és újabb igényeket támaszt az élelmiszerekkel szemben. Ennek ellenére a marketing föként a fiatal generációt célozza meg, kevésbé veszi figyelembe a jelentős potenciált képviselő idösebb, érett generáció igényét. A fejlett országokban az idősödő társadalom tényét felismerve elkezdetek alkalmazkodni az új születöben levö igényekhez, s stratégiảjukat ennek megfelelöen alakítani, hogy "senior-barát" termékeket hozzanak létre a különböző javak és szolgáltatások piacán (PETTIGREW, 2005). A felgyorsult változások sorozata felveti a kérdést, hogy a jelen idő szeniorjának kialakított termékek mennyire lesznek majd a közeljövő szeniorjainak számára megfelelöek. A kiadási szerkezetet vizsgálva megállapítható, hogy az élelmiszerek szerepe a fogyasztási szerkezetben jelentös, de a tendenciáját vizsgálva egyre kisebb részt foglal el. Általánosságban elmondható, hogy a fogyasztás - egy-két termék kivételével - csökken, mennyiségi telítỏdéssel szembesülünk (KESZTHELYINÉ, 2004; LEHOTA, 2004), de az egészségmegörzés és az 
élelmiszerbiztonsági okok miatt a jelentősége tovább fokozódik. A magyar társadalomban is várható, hogy a fogyasztási javak minőségének, és azok származásának egyre nagyobb jelentőséget tulajdonítanak a fogyasztók a vásárlásaik során.

\section{AZ AKTÍV IDŐSKORI ÉLELMISZERFOGYASZTÁS IDŐBELI ASPEKTUSAI}

$\mathrm{Az}$ 1. ábrán látható konstrukció - egyfajta bevezetésként - az aktív időskori élelmiszerfogyasztás időbeli aspektusaira terjed ki. Hărom idősík segítségével (múlt, jelen, jövő) magyarázza a vizsgált szegmens szokásainak változásait, és próbálja felvezetni az egyes alapvető tényezőket.

A múlt egy fontos meghatározó jellemzője az élelmiszerfogyasztás területén a tapasztalat és a normák. Az információáramlás szükössége eredményezte az apáról-fiủra, anyáról-leányra szálló tapasztalatcserét, illetve hagyományőrzést. A táplálékforrások behatároltsága lényegében a technikai fejletlenség eredménye. Számos élelmiszer kizárólag szezonális jelleggel volt fogyasztató, mivel eltarthatóságuk szük korlátok között mozgott. A beszerzési módok behatároltak voltak, leggyakrabban közvetlen a termelőtől történt. A világgazdaság kialakulása előtt a piacok helyi és regionális léptéküek voltak. A múltra jellemző tényezők azonban számos téren elönyt képviseltek, pl. a közvetlen termelötöl való beszerzés biztonságérzetet, illetve frissességet jelentett a vásárlónak. Tapasztalataik és lehetőségeik révén próbálták az eltarthatóságot is növelni, különféle eljárások és a tároló kamrák segítségével.

A jelenkor a határtalan áruáramlás és információáramlás jegyében telik. Az élelmiszerpiacon az elmúlt években bekövetkezett, $s$ a közeljövöben beteljesülő változások az alábbiakra vezethetők vissza: öregedő népesség, az egyfős háztartások számának növekedése, az egészséggel való több törỏdés, változó foglalkoztatási struktúra, gyors technológiai fejlödés, nemzetközi utazások bővülése, a média erősödő szerepe.

A születéskor várható élettartam a vizsgált időszakban összességében javult Magyarországon. Az egyik oldalon ez tény magyarázható a megváltozott életstílussal, életmóddal, életszínvonallal. A másik oldalon viszont az orvostudomány olyan betegségeket kiváltó faktorok nagyarányú felbukkanásáról informálja a lakosságot, amely tudatosan vezet a táplálkozási szokásaink megváltoztatásához (pl. allergia, élelmiszerekre való érzékenység, szív- és érrendszeri betegségek, emésztőrendszer betegségei, stb.). Számos esetben azonban az eltarthatóságra való törekvés egyik következménye a túlzott tartósítószer adagolása az élelmiszerekbe, amely allergiás tünetek kialakulásához vezethet. A határtalan élelmiszerválaszték napjaink egyik meghatározó eleme, megszünőben a szezonalitás - export, import tevékenységek hatására - éves életritmust kialakító jelensége, illetve megszüntek az áthidalhatatlan távolságok (SIMAI, 2007; NEMES NAGY, 2008). Az egyik oldalról ezt a nemzetközi utazások bövülése eredményezte, a másik oldalról pedig azoknak az élelmiszerkereskedelmi láncolatoknak az elterjedése, akik egész évben biztosítani tudják a fogyasztói igények szerinti áruválasztékot.

A nem lehetetlen jövőt próbáljuk meg kitapintani és a jelenből kiindulva továbbgondolni (NOVÁKY, 2006). A fogyasztási szerkezet átalakulása tovább folytatódik. Az időskorú fogyasztókra jellemző lesz a közeljövő orientáltság, mint a magatartási elemek alapvető tényezője. Rendkívül komoly következményei lehetnek ugyanis az egészségtudatosságra, egészséggel kapcsolatos döntésekre, továbbá az egészségi állapot alakulására is. A tömegtájékoztatás egyik fontos vetülete lehetne a valós tényeken és összefüggéseken alapuló élelmiszer- és táplálkozásismeret, mivel ezek birtokában az ember már saját maga is javíthatja az egészségét.

Összességében elmondható, hogy kibontakozóban van a vásárlási-fogyasztási szokások új hulláma, amely formálja a középkorúak magatartását és beépíthető az időskori fogyasztók mindennapjaiba: 
- nö a természetes eredetü ("bio" stb.) termékek népszerüsége;

- tovább növekszik a funkcionális élelmiszerek iránti igény;

- fokozódik az egészséges táplálkozásra való törekvés;

- a kis idōráforditással készíthetö "kényelmi" termékek értékesítése bövül;

- a vásárlásra fordított idő mérséklödik, az egy helyen egy hétre való vásárlás nyer teret;

- a házon kívüli étkezés több változattal bővül.

Az időskori élelmiszerfogyasztás aspektusai közül a hasznosság (hasznosulás) nyomon követése a modellben az utolsó fázis. A múltban nem tulajdonítottak ennek nagy jelentőséget, hiszen a puszta létfenntartás volt a cél. A jelenben és a jövöben viszont fokozott jelentőséggel bír az életminőség is. A termék tulajdonságait a fogyasztó elöször is azok hasznossága alapján rangsorolja. A hasznosság, a vásárló elözetes ismeretei és személyes tapasztalata alapján körvonalazódik. Az élelmiszerek kritikus tulajdonságai különösen fontosak a fogyasztó számára, pl: íz, frissesség, egészségesség és az ár. A bizonytalansági faktorokat figyelve tudni kell, hogy az általában vett időskori fogyasztót sohasem ismerhetjük pontosan, hiszen rendkívül nagyfokú az öregek heterogenitása. Továbbá folyamatosan változik az egyén lelkiállapota, jövedelmi helyzete, egészségügyi állapota, és ezek függvényében az élelmiszerfogyasztásának hasznosságát gyakran átértékelheti. Pontosan ezért a termék értékének maximalizálásához folyamatosan nyomon kell követni e fragmentálódó réteg fogyasztói magatartás változásait, illetve a nekik címzett kritikus terméktulajdonságokat.

\section{AZ AKTÍV IDŐSKORI MINŐSÉG-ÉS EGÉSZSÉGTUDATOS ÉLELMISZETFOGYASZTÁS JÖVŐORIENTÁLT MODELLJE}

A 2. ábrán látható modellnek három alapvető kiindulópontja van:

- gazdasági és társadalmi (kulturális) tényezők;

- az individuumhoz kötődő tényezők;

- élelmiszerhez kötődő tényezők.

Felvázolásakor a klasszikussá vált PILGRIM-féle (1957) élelmiszer-fogyasztói magatartási modellböl indultunk ki. E modell alapvetö meghatározója az észlelés. Kiinduló pont az élelmiszer fizikai és kémiai jellemzői, melyek a fiziológiai szükségletre vannak hatással. A vásárlás/fogyasztás során az egyén az észlelt valóság és az objektív valóság különbségeit próbálja meg kiegyenlíteni (kognitív disszonancia). Tehát az élelmiszerfogyasztási magatartás kapcsán gondolatainkban és cselekedeteinkben gyakran ellentmondást fedezhetünk fel.

A gazdasági és társadalmi tényezők elemzésénél fontosnak tartható az idösödő korban átalakuló jövedelemszerzési pozíció és a társas kapcsolatok. Ezekhez a módosuló helyzetekhez igazodva fontos a fogyasztó számára a saját hatékonyságának felmérése, mivel fogyasztását arányba kell állítani a jövedelmi szinttel.

A magyar lakosság egészségi állapota aggasztóan romlik (GAÁL, 1998). A gyorsuló életritmus, a civilizáció megköveteli az egészséges életmódra nevelést. A megfelelő egészségi állapot fenntartása nagymértékben tudatos törekvés és erőfeszités eredménye, hiszen a személy nem pusztán passzív elszenvedöje azoknak a körülményeknek, amelyek közt jól vagy rosszul érzi magát, hanem megteremtöje is.

A személyhez kötődő faktorok egyértelmüen a pszichikai tényezőkön alapulnak. Három alcsoportot lehet kialakítani a kutatásunk tárgya kapcsán: a konkrét kognitív tényezök, észlelési tényezők, befolyásoló tényezők és az indítékok. A konkrét kognitív tényezöknél alapvető az egészség fontossága (relatív fontosság), a külső egészségügyi kontroll, illetve az észlelt egészségi állapot. A pszichikai tényezők kapcsolódnak a termékek során megjelenő relativ attitüddel. Tehát ebben az esetben kifejezi, hogy a fogyasztó miként viszonyul az 
élelmiszerhez (HOFMEISTER-TÓTH, 2006). Mivel a megismerés, a tanulás megelözi az attitüd kialakulását és megváltozását, fontos szerepe lehet a marketingnek. A kommunikáció hatékony alkalmazása, a kulturális kontextusba ágyazott egyéni szokásokkal karöltve, ráirányithatja a figyelmet az ételkészités módjainak fontosságára, elősegíti az egészségtudatos életformán, illetve értékracionális gondolkodáson (SZÁNTÓ, 1998) alapuló élelmiszerfogyasztást.

$\mathrm{Az}$ élelmiszerhez kötődő tényezök az élelmiszerminöségi tényezők és az élelmiszertulajdonságok. A fogyasztók egészségtudatosabb csoportjánál egyre jellemzöbbé válik, hogy elfordulnak a tömegtermékektöl, tudatosan keresik a magasabb hozzáadott értékkel rendelkezö, különleges minöségü, speciális táplálkozási igényt kielégítő termékeket. Mai viszonylatban, amikor minőségröl beszélünk, egyrészröl a táplálkozási elönyt értjük, a másikról pedig a természetességet, élvezeti értéket, az elfogadható árat, összefoglalva tehát a piacképességet (LAKNER-SARUDI, 2004). Az élelmiszergyártók funkcionális élelmiszereket fejlesztenek, amelyek összetételét módosítják: egyes komponenseket szegényítik, más komponenseit dúsítják. Az ilyen típusú élelmiszereknek pozitív hatása lehet több élettani funkció esetében, ami jobb egészségi állapotban, kellemesebb közérzetben és egyes betegségek kockázatának csökkentésében mutatkozhat meg (SZAKÁLY-BERKE, 2004). A funkcionális élelmiszerek hivatottak tápláló jellegük mellett fokozni a szervezet védekező mechanizmusait, megakadályozzák egyes betegségek kialakulását (magas vérnyomás, cukorbetegség), segítik az egyes betegségékböl való felgyógyulást, fenntartják a fizikai és testi kondíciót és lassítják az öregedést. Bizonyított összefüggéseknek már manapság is birtokában vagyunk. Például a szines gyümölcsökben és a zöldségekben található a legtöbb antioxidáns, melyek fokozzák a szervezet ellenállóképességét és megnövelik az élettartamot, igaz nem lassítják az öregedési folyamatot. Ha viszont már a napi 1500 kalóriás föleg gyümölcsökböl és zöldségekböl álló szigorú diétát képes valaki betartani, akkor a csökkenő testhömérséklet és állandó éhségérzet mellett az öregedési folyamat is lelassítható (LÁSZLÓ-FALUS, 2002, 407-408). A felsoroltakból következtetni lehet az idősödő korosztály specifikus szükségleteire és eljuthatunk a tudatos és jövőorientált élelmiszerválasztáshoz. A jövőorientáltság, mint magatartási elem fontos tényezö (HIDEG, 2007), mert mint beállítódottság, rendkívül komoly következményei lehetnek az időskorúak egészségtudatosságára, egészséggel kapcsolatos döntéseire és így egészségi állapotuk alakulására is.

CSETE és LÁNG (1999) a minőséget valamennyi meghatározó dimenziójában igyekszik megragadni, amikor felállitja minőség-modelljét. Értelmezésük szerint a minőség összetett, komplex, többtényezős rendszerbiológiai, müszaki, technológiai, közegészségügyi, fogyasztói, piaci, táplálkozás-élettani, környezeti, élelmiszer- és élelmiszerbiztonsági stb. vonatkozásokkal és bonyolult, soktényezős folyamatokkal. Tömörebb megfogalmazás szerint: „a minőség a célnak való megfelelés". 
1. ábra: Az aktív időskori élelmiszerfogyasztás időbeli aspektusai

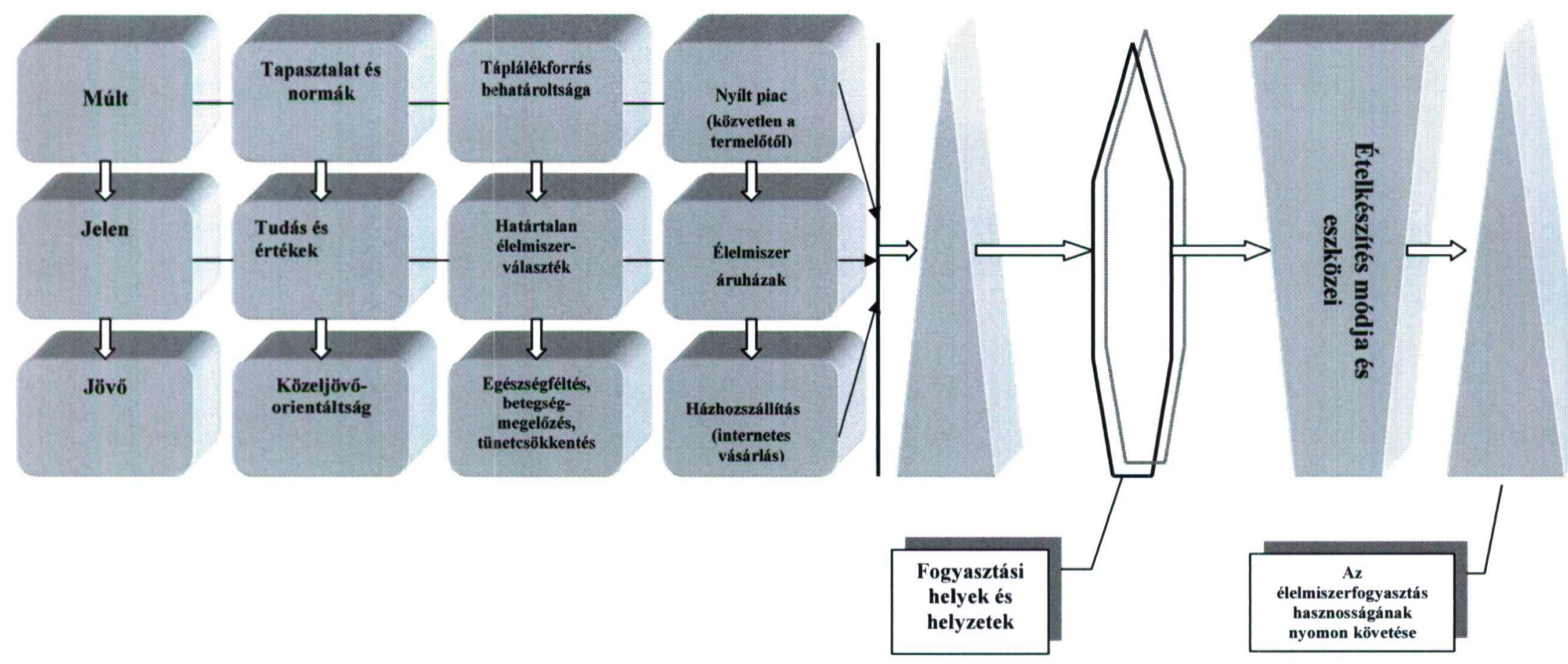

Forrás: a szerző saját szerkesztése 
2. ábra: Az aktív időskori minőség- és egészségtudatos élelmiszerfogyasztás jövőorientált modellje

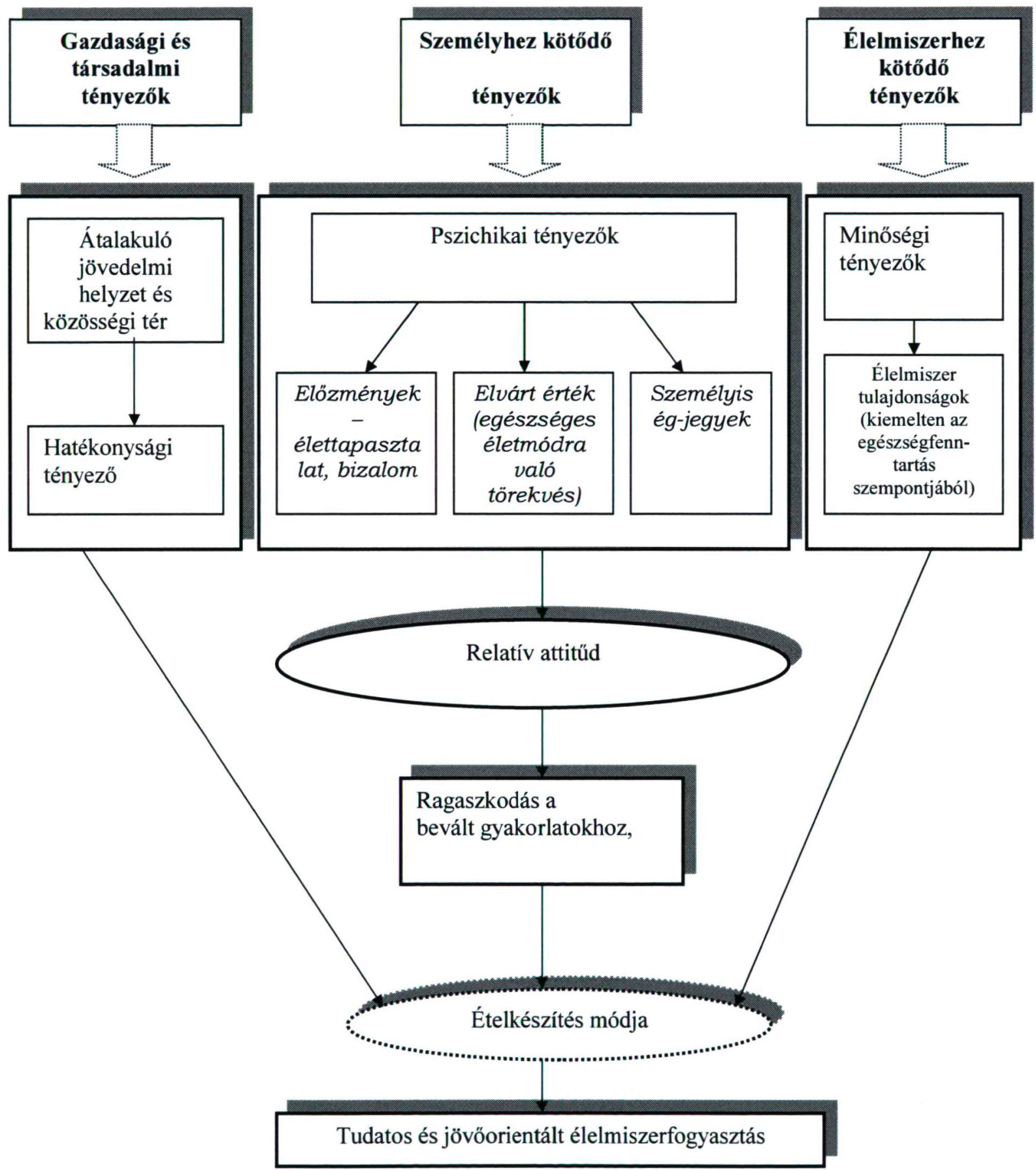




\section{4. ÖSSZEFOGLALÓ MEGÁLLAPITTÁSOK, KÖVETKEZTETÉSEK, JAVASLATOK}

$\mathrm{Az}$ idősödés nem csak kihívás az élelmiszert elöállítók számára, hanem új lehetőségek tárháza is a termékfejlesztés és innovációs tevékenységek terén. Specifikusan az időskorúakra szabott élelmiszerfogyasztási magatartási modelljeinket abból a célból dolgoztuk ki, hogy felhívjuk a gyártók, termelök figyelmét ezen egyre bővülő piaci szegmens, a többi korosztálytól eltérō igényeire. Nem süríthetö egy modellbe az önmagában is heterogén időskorú populáció élelmiszerfogyasztói magatartása. A két hipotetikus modell kidolgozásával a kezdő lépéseket kívántuk megtenni e téma kutatása érdekében. Közeljövöbeli célunk, hogy a valóságban is teszteljük általános modelljeinket a termelöi és fogyasztói oldalon egyaránt. A modellekböl következtetni lehet az idősödő korosztály specifikus szükségleteire. A modulokat végigjárva eljuthatunk a bölcsességen alapuló és/vagy jövöorientált élelmiszerválasztáshoz. A jövőorientáltság, mint magatartási elem fontos tényező, mert mint beállitódottság, rendkívül komoly következményei lehetnek az időskorúak minőség- és egészségtudatosságára, a táplálkozással kapcsolatos döntéseire és így végső soron egészségi állapotuk és jólétük alakulására is.

\section{FELHASZNÁLT IRODALOM}

Cseres-Gergely Zsombor - Molnár György (2008): Háztartási fogyasztói magatartás és jólét Magyarországon a rendszerváltás után. Közgazdasági Szemle Vol. 55. No. 2. 107-135. o.

Csete László - Láng István (1999): Minőség és agrárstratégia. Magyar Tudományos Akadémia, Budapest, 15-38. o.

Gaál Béla (1998): A magyar háztartások élelmiszerfogyasztási szokásai. Marketing\&Menedzsment, Vol. 50. No.3. 71-75. o.

Hideg Éva (2007): A forecasttól a foresightig. Magyar Tudomány, Vol. 168. No. 9. 11671170. 0 .

Hofmeiter - Tóth Ágnes (2006): Fogyasztói magatartás. AULA Kiadó, Budapest.

Keszthelyiné Rédei Mária (2004): Az időskorú háztartások fogyasztási színvonala és szerkezete. In: Időskoríak Magyarországon. KSH, Budapest, 144-174. o.

Lakner Zoltán - Sarudi Csaba (2004): Ways and deadlocks in the strategic development of the Hungarian food chain. Gazdálkodás, Vol. 49. No. 8. 48-57. o.

László Valéria - Falus András (2002): Az öregedés sejttani és genetikai alapjai. Magyar Tudomány, Vol. 58. No. 4. 406-411. o.

Nemes Nagy József (2008): A tér a társadalomkutatásban. Akadémiai Kiadó, Budapest.

Nováky Erzsébet (2006): Jövökutatás és felelősség. Magyar Tudomány, Vol. 167. No. 9. 1090-1098. o.

Pettigrew, A.M. (2005): Segment with segments: Younger and Older Seniors Expectations of Financial Planning Service. Journal of Research for Consumer, Issue 7. 24-34. 0.

Pilgrim, F.J. (1957): The Component of Food Acceptance and Their Measurement. American Journal of Clinical Nutriton, Vol. 5. No. 2. 171-175. o.

Simai Mihály (2007): A világ a XXI. század forgatagában: útelágazások és útvesztők. Akadémiai Kiadó, Budapest.

Szakály Zoltán - Berke Szabolcs (2004): A táplálkozás, a minőség és a marketing kapcsolata élelmiszereknél. In: Berács, J. -Lehota, J. -Piskóta, I. -Rekettye, G.(szerk.): Marketingelmélet a gyakorlatban. KJK Kerszöv, Budapest, 319-335. o.

Szántó Zoltán (1998): A racionális döntések elméletén nyugvó társadalomtudomány. In: Csontos László (vál.) A racionális döntések elmélete. Osiris-Láthatatlan Kollégium, Budapest, 7-24. o. 